\title{
Tranexamic acid in coronary artery surgery: One-year results of the Aspirin and Tranexamic Acid for Coronary Artery Surgery (ATACAS) trial
}

Paul S. Myles, MD, DSc, , Julian A. Smith, MS, FRACS, ${ }^{\text {b,c }}$ Jessica Kasza, BSc(Hon), PhD, ${ }^{b}$

Brendan Silbert, MB BS, FANZCA, ${ }^{\mathrm{d}}$ Mohandas Jayarajah, MB BS, FRCA, ${ }^{\mathrm{e}}$ Thomas Painter, MB ChB, FANZCA, ${ }^{\mathrm{f}}$ D. James Cooper, MD, FCICM, ${ }^{\mathrm{a}, \mathrm{b}}$ Silvana Marasco, PhD, FRACS, ${ }^{\mathrm{a}, \mathrm{b}}$ John McNeil, PhD, FRACP, ${ }^{\mathrm{b}}$ Jean S. Bussières, MD, FRCPC, ${ }^{\mathrm{g}}$ Shay McGuinness, MB ChB, FANZCA, ${ }^{\text {h }}$ Kelly Byrne, MB ChB, FANZCA, ${ }^{\mathrm{i}}$ Matthew T. V. Chan, MB BS, PhD,${ }^{\mathrm{j}}$ Giovanni Landoni, MD, ${ }^{\mathrm{k}}$ Sophie Wallace, BSc, MPH, ${ }^{\mathrm{a}, \mathrm{b}}$ and Andrew Forbes, MSc, PhD, ${ }^{\mathrm{b}}$ for the ATACAS investigators and the ANZCA Clinical Trials Network

\section{ABSTRACT}

Background: Tranexamic acid reduces blood loss and transfusion requirements in cardiac surgery but may increase the risk of coronary graft thrombosis. We previously reported the 30-day results of a trial evaluating tranexamic acid for coronary artery surgery. Here we report the 1-year clinical outcomes.

Methods: Using a factorial design, we randomly assigned patients undergoing coronary artery surgery to receive aspirin or placebo and tranexamic acid or placebo. The results of the tranexamic acid comparison are reported here. The primary 1-year outcome was death or severe disability, the latter defined as living with a modified Katz activities of daily living score of less than 8 . Secondary outcomes included a composite of myocardial infarction, stroke, and death from any cause through to 1 year after surgery.

Results: The rate of death or disability at 1 year was $3.8 \%$ in the tranexamic acid group and $4.4 \%$ in the placebo group (relative risk, $0.85 ; 95 \%$ confidence interval, $0.64-1.13 ; P=.27$ ), and this did not significantly differ according to aspirin exposure at the time of surgery (interaction $P=.073$ ). The composite rate of myocardial infarction, stroke, and death up to 1 year after surgery was $14.3 \%$ in the tranexamic acid group and $16.4 \%$ in the placebo group (relative risk, $0.87 ; 95 \% \mathrm{CI}, 0.76-1.00 ; P=.053)$.

Conclusions: In this trial of patients having coronary artery surgery, tranexamic acid did not affect death or severe disability through to 1 year after surgery. Further work should be done to explore possible beneficial effects on late cardiovascular events. (J Thorac Cardiovasc Surg 2019;157:644-52)

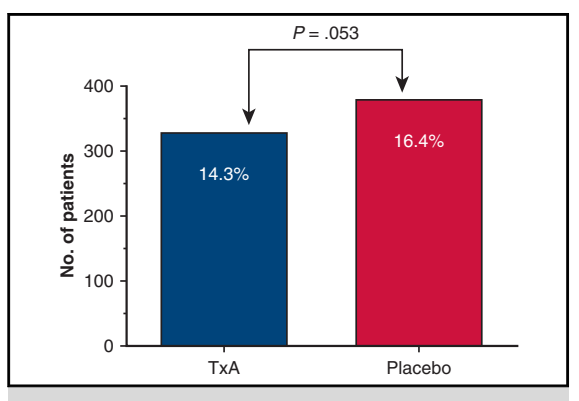

Major adverse cardiovascular events (MACE) at 1 year after surgery.

\section{Central Message}

Tranexamic acid reduces bleeding complications at the time of surgery without a longer-term thrombotic risk. Tranexamic acid may also improve disability-free survival in aspirin-exposed patients.

\section{Perspective}

Although bleeding is of concern for patients undergoing coronary artery surgery, the greater risk comes from thrombotic events. There has been a concern that antifibrinolytic drugs may increase graft thrombosis, leading to late myocardial infarction and heart failure. Aspirin may mitigate such an effect.

See Editorial Commentary page 653.

\footnotetext{
From the a Department of Anaesthesia and Perioperative Medicine, Alfred Hospital, Melbourne, Australia; 'bepartment of Anaesthesia and Perioperative Medicine, Monash University, Melbourne, Australia; ' Department of Cardiothoracic Surgery, Monash Medical Centre, Clayton, Australia; ${ }^{\mathrm{d} D e p a r t m e n t}$ of Anaesthesia, St Vincent's Hospital, Fitzroy, Australia; ${ }^{\mathrm{e}}$ Department of Cardiothoracic Anaesthesia and Cardiac Critical Care, South West Cardiac Centre, Derriford Hospital, Plymouth, United Kingdom; ${ }^{\mathrm{f}}$ Royal Adelaide Hospital and Discipline of Acute Care Medicine, University of Adelaide, Adelaide, Australia; ${ }^{\mathrm{g}}$ Department of Anesthesiology, Institut Universitaire de Cardiologie et de Pneumologie de Québec, Quebec City, Quebec, Canada; ${ }^{\mathrm{h}}$ Department of Cardiothoracic \& Vascular Intensive Care

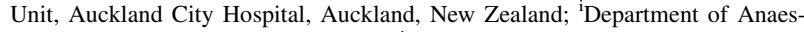
thesia, Waikato Hospital, New Zealand; ${ }^{\mathrm{j}}$ Department of Anesthesiology and Intensive Care, The Chinese University of Hong Kong, Hong Kong, China; and ${ }^{\mathrm{k}}$ Department of Anesthesia and Intensive Care, IRCCS San Raffaele Scientific Institute and Vita-Salute San Raffaele University, Milan, Italy.

Participating centers and investigators in the Aspirin and Tranexamic Acid for Coronary Artery Surgery (ATACAS) Trial are listed in the Appendix E1.
}

The study sponsor was the Alfred Hospital, Melbourne, Australia. The study was supported by grants from the Australian National Health and Medical Research Council (NHMRC, ID 334015 and 1009203); the Australian and New Zealand College of Anaesthetists; and the UK National Institute of Health Research. Paul Myles is supported by an Australian NHMRC Practitioner's Fellowship.

CLINICAL TRIAL REGISTRATION: URL: www.anzctr.org.au. Unique identifier: ACTRN12605000557639.

Received for publication April 16, 2018; revisions received Sept 13, 2018; accepted for publication Sept 27, 2018; available ahead of print Nov 17, 2018.

Address for reprints: Paul S. Myles, MD, DSc, Department of Anaesthesia and Perioperative Medicine, Alfred Hospital, Commercial Rd, Melbourne, Victoria, 3004, Australia (E-mail: p.myles@alfred.org.au). $0022-5223 / \$ 36.00$

Copyright $(\subset) 2018$ by The American Association for Thoracic Surgery https://doi.org/10.1016/j.jtcvs.2018.09.113 


\section{Abbreviations and Acronyms}

ADL = activities of daily living

ATACAS $=$ Aspirin and Tranexamic Acid for

Coronary Artery Surgery

MACE $=$ major adverse cardiovascular events

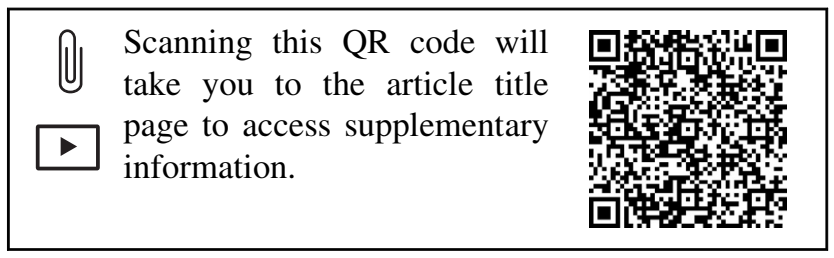

Tranexamic acid is a potent antifibrinolytic agent that has been shown to reduce surgical bleeding and perioperative blood transfusion ${ }^{1}$ and can be considered a standard of care in millions of cardiac surgical operations worldwide. However, this blood-sparing benefit might increase susceptibility to coronary artery graft thrombosis, leading to greater risk of late thrombotic events. Some drugs used to reduce bleeding in cardiac surgery have been associated with increased thrombotic complications or death, ${ }^{2-5}$ and tranexamic acid has also been implicated. ${ }^{6}$ In contrast, the reduction in need for blood transfusion during and after surgery might lead to a long-term outcome benefit. $^{7,8}$

Coronary graft failure occurs in up to $25 \%$ of saphenous vein grafts and $5 \%$ of arterial grafts at 1 year after surgery, but the clinical consequences vary according to the type, location, and reason for the failed graft. ${ }^{9,10}$ Intraoperative and postoperative low-flow states, endothelial injury, blood product transfusion, and hypercoagulable states each increase the potential for early graft thrombosis and so place the patient at increased risk of early and late cardiac events. In the Aspirin and Tranexamic Acid for Coronary Artery Surgery (ATACAS) trial, we reported that, at 30 days after surgery, tranexamic acid did not increase the risk of thrombotic complications but reduced bleeding complications and need for blood transfusion during and after surgery. ${ }^{11}$

Restoration of health, functional capacity, and emotional well-being are highly valued patient goals after surgery. ${ }^{12}$ Another consideration when evaluating outcomes after major surgery is the actual impact of various cardiovascular complications on longer-term health, and this is particularly relevant in elderly patients. ${ }^{12-14}$ "Successful aging" emphasizes intact physical function and being free of disability. ${ }^{15}$ Given that longer-term disability-free survival is the overarching goal of most cardiac surgery, it deserves to be a specific endpoint in evaluations of treatments in this setting. We thus conducted a 1-year follow up study to determine whether tranexamic acid affected long-term risk of death or disability and myocardial infarction and stroke after cardiac surgery.

\section{METHODS \\ Trial Design}

ATACAS was an international, randomized, double-blind, 2-by-2 factorial trial conducted at 31 centers in 7 countries to separately assess safety and effectiveness of aspirin (reported elsewhere in the Journal) and tranexamic acid in patients undergoing coronary artery surgery. The rationale and design of the ATACAS trial, ${ }^{16}$ the 30 -day results of the aspirin intervention, ${ }^{17}$ and of the tranexamic acid intervention, ${ }^{11}$ have been previously reported. In July 2008, the members of the ATACAS steering committee incorporated a 1-year follow-up that included measurement of patient disability (lead site: Alfred Hospital Ethics Committee, Melbourne, Australia) in the study procedures. The follow-up study was approved by the ethics committee at each participating center, and patients provided signed written informed consent before enrollment.

\section{Patient Selection}

Eligible participants included adults who were at increased risk of major complications and who were having on-pump or off-pump coronary artery surgery, with or without valvular or other procedures. Patients may or may not have been exposed to aspirin therapy according to the factorial randomization schedule if they were enrolled before closure of the aspirin arm of the trial, or as part of clinical decision-making subsequently.

\section{Study Medication}

Tranexamic acid, 50 to $100 \mathrm{mg}$ per $\mathrm{kg}$, or $0.9 \%$ saline (placebo) was administered as an intravenous infusion over 30 minutes after induction of anesthesia for surgery, aiming to maintain an effective plasma concentration for about 6 to 8 hours in the active group. ${ }^{1,18}$ For tranexamic acid, we encouraged local blinding of the drug preparation but allowed the attending anesthesiologist to prepare study drug if research personnel were not available, and this detail was recorded.

\section{Randomization, Blinding, and Data Quality}

Patients were randomly assigned to treatments in permuted blocks, using a computer-generated code. With the occasional exception of the attending anesthesiologist, all surgical and research staff were kept blinded to tranexamic acid/placebo group allocation.

A blinded Clinical Endpoints Committee who did not participate in the study adjudicated all thrombotic events through to 30 days after surgery. Later thrombotic events were accepted if diagnosed by the treating physician and documented in the medical record. Study center visits with random audits were conducted during the enrollment period, a Data Quality Committee-monitored data completion and accuracy. An independent Data Safety and Monitoring Committee monitored the study for safety.

\section{Measurements and Patient Follow-up}

Patient demographic and perioperative characteristics were recorded. Patient follow-up was planned for 30 days after surgery (as previously reported $)^{11}$ and at 1 year, presented here. Survival and clinical status were evaluated using a review of the medical records and patient contact via telephone. For myocardial infarction, stroke or death occurring after 30 days through to 1 year after surgery, we required source documentation 


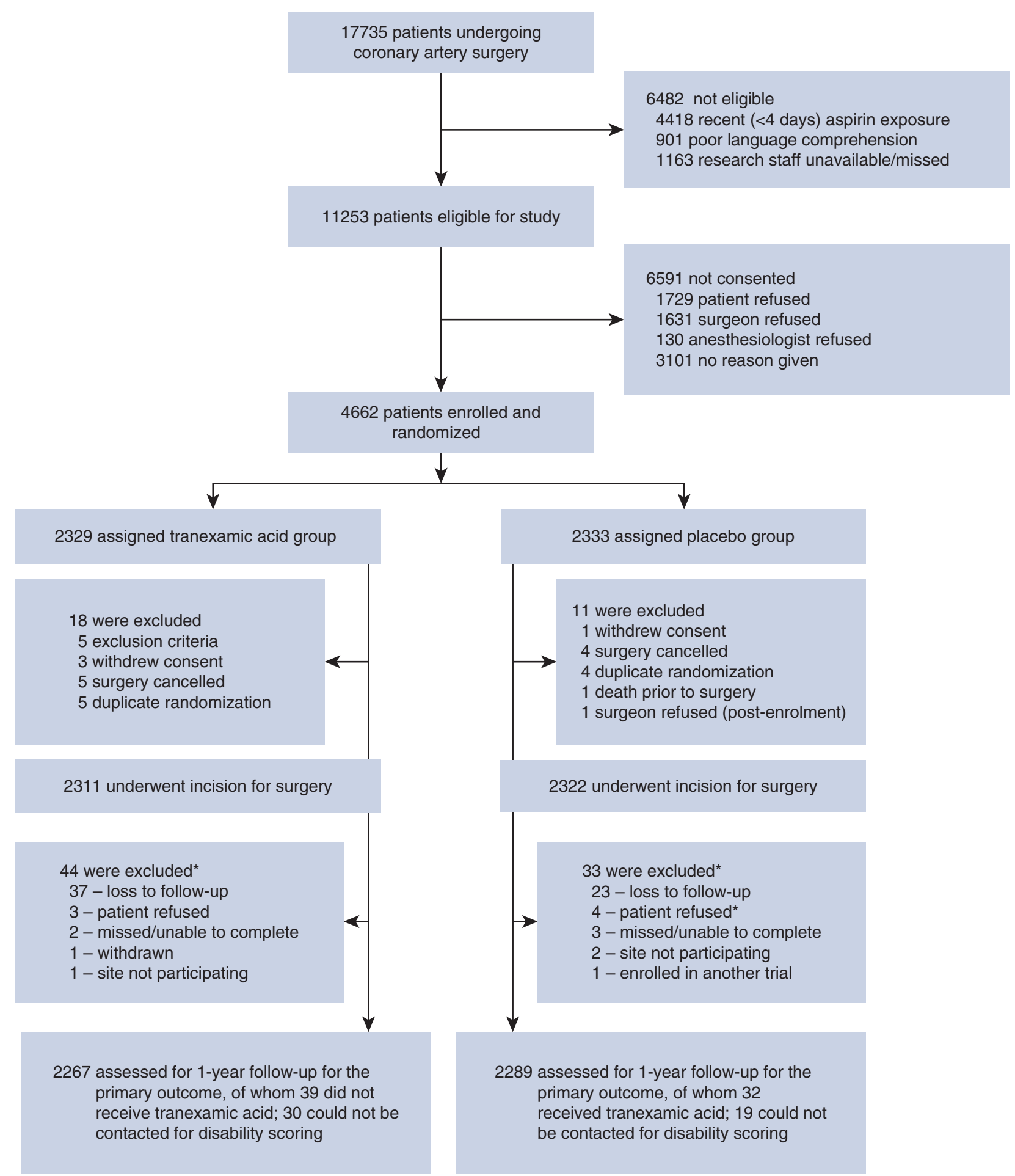

FIGURE 1. Enrollment, randomization, and assessment. One-year follow-up completed in $97.1 \%$ eligible and assigned tranexamic acid or placebo. *Three patients in the tranexamic acid group and 4 patients in the placebo group had a myocardial infarction or stroke within 30 days or surgery; these data were included in the secondary outcome analysis. 
TABLE 1. Baseline patient and surgical characteristics of the 1-year cohort

\begin{tabular}{|c|c|c|}
\hline Characteristic & $\begin{array}{l}\text { Tranexamic acid } \\
\quad(N=2237)\end{array}$ & $\begin{array}{c}\text { Placebo } \\
(\mathbf{N}=\mathbf{2 2 7 0})\end{array}$ \\
\hline Age, y & $67.0 \pm 9.7$ & $67.1 \pm 9.5$ \\
\hline Weight, kg & $86.4 \pm 17.4$ & $85.7 \pm 16.6$ \\
\hline Male sex, n (\%) & $1868(83.5)$ & $1888(83.2)$ \\
\hline \multicolumn{3}{|l|}{ NYHA classification, n (\%) } \\
\hline 1 & 407 (18.2) & $455(20.0)$ \\
\hline 2 & $1170(52.3)$ & $1136(50.0)$ \\
\hline 3 & $600(26.8)$ & $622(27.4)$ \\
\hline 4 & $59(2.6)$ & $57(2.5)$ \\
\hline \multicolumn{3}{|l|}{$\begin{array}{l}\text { Pre-existing medical conditions, } \\
\qquad \mathrm{n}(\%)\end{array}$} \\
\hline Diabetes & $765(34.2)$ & $782(34.4)$ \\
\hline Renal impairment & 169 (7.6) & $167(7.4)$ \\
\hline Hypertension & 1757 (78.5) & 1813 (79.9) \\
\hline Angina & $1537(68.7)$ & 1549 (68.2) \\
\hline Heart failure & $232(10.4)$ & $242(10.7)$ \\
\hline Myocardial infarction within $90 \mathrm{~d}$ & $883(39.5)$ & $884(38.9)$ \\
\hline Endocarditis & $7(0.3)$ & $1(0.0)$ \\
\hline Cerebrovascular disease & $213(9.5)$ & $226(10.0)$ \\
\hline Peripheral vascular disease & $224(10.0)$ & $234(10.3)$ \\
\hline Pulmonary hypertension & $129(5.8)$ & $104(4.6)$ \\
\hline Previous angioplasty/stent & $57(2.5)$ & $57(2.5)$ \\
\hline Thrombolysis on this admission & $12(0.5)$ & $22(1.0)$ \\
\hline Smoking history & $1432(64.0)$ & $1538(67.8)$ \\
\hline Respiratory disease & $308(13.8)$ & 339 (14.9) \\
\hline $\begin{array}{l}\text { Chronic obstructive pulmonary } \\
\text { disease }\end{array}$ & $216(9.7)$ & $233(10.3)$ \\
\hline \multicolumn{3}{|l|}{ Preoperative medications, n (\%) } \\
\hline $\begin{array}{l}\text { ACE inhibitor/angiotensin } \\
\text { receptor blocker }\end{array}$ & $1494(66.8)$ & $1532(67.5)$ \\
\hline Beta-blocker & 1514 (67.7) & 1509 (66.5) \\
\hline Calcium channel blocker & $685(30.6)$ & $766(33.7)$ \\
\hline Nitrate & $879(39.3)$ & $872(38.4)$ \\
\hline Statin & $1948(87.1)$ & $2004(88.3)$ \\
\hline Amiodarone & $22(1.0)$ & $41(1.8)$ \\
\hline Digoxin & $54(2.4)$ & $46(2.0)$ \\
\hline Diuretic & $561(25.1)$ & $517(22.8)$ \\
\hline Aspirin within $4 \mathrm{~d}$ & $1468(65.6)$ & $1496(65.9)$ \\
\hline Clopidogrel within $7 \mathrm{~d}$ of surgery & $64(2.9)$ & $66(2.9)$ \\
\hline Warfarin within $7 \mathrm{~d}$ of surgery & $26(1.2)$ & $24(1.1)$ \\
\hline Heparin in previous $24 \mathrm{~h}$ & $165(7.4)$ & $181(8.0)$ \\
\hline Previous cardiac surgery & 37 (1.7) & $27(1.2)$ \\
\hline \multicolumn{3}{|l|}{ Surgery status, n (\%) } \\
\hline Elective surgery & $1610(72.0)$ & $1609(70.9)$ \\
\hline Isolated CABG surgery & $1689(75.5)$ & $1759(77.5)$ \\
\hline $\begin{array}{l}\text { Combined CABG-valvular } \\
\text { surgery }\end{array}$ & $475(21.2)$ & $431(19.0)$ \\
\hline On-pump surgery & $2170(97.0)$ & $2197(96.8)$ \\
\hline Off-pump surgery & $65(2.9)$ & $72(3.2)$ \\
\hline Open chamber surgery & $500(22.4)$ & $465(20.5)$ \\
\hline
\end{tabular}

(Continued)
TABLE 1. Continued

\begin{tabular}{lcc}
\hline \multicolumn{1}{c}{ Characteristic } & $\begin{array}{c}\text { Tranexamic acid } \\
(\mathbf{N}=\mathbf{2 2 3 7})\end{array}$ & $\begin{array}{c}\text { Placebo } \\
(\mathbf{N}=\mathbf{2 2 7 0})\end{array}$ \\
\hline $\begin{array}{c}\text { Coronary artery grafting } \\
\text { Number of distal grafts, } \\
\text { median (IQR) }\end{array}$ & $3(2-4)$ & $3(2-4)$ \\
$\begin{array}{c}\text { Internal mammary artery } \\
\text { graft(s), n (\%) }\end{array}$ & $2012(90.1)$ & $2051(90.5)$ \\
$\begin{array}{l}\text { Crossclamp time, min, } \\
\text { median (IQR) }\end{array}$ & $69(50-90)$ & $64(48-88)$ \\
$\begin{array}{c}\text { Postoperative aspirin } \\
\text { within } 24 \text { h, n }(\%)\end{array}$ & $1870(84.8)$ & $1813(81.1)$ \\
\hline
\end{tabular}

Data are reported as mean \pm SD when appropriate. NYHA, New York Hear Association, $A C E$, angiotensin-converting enzyme; $C A B G$, coronary artery bypass graft; $I Q R$, interquartile range.

in the patient's medical record. If the patient informed us that the thrombotic event was managed at another hospital, we sought clinical documentation via them or their local medical practitioner.

Measurement of functional status at 1 year after surgery was based on the Katz independent activities of daily living (ADL) index, ${ }^{19}$ which originally included 3 categories representing degrees of function for each of the 6 ADL domains (moving in and out of a chair or bed, using the toilet, bathing or showering, walking across a room, eating, and dressing). For each domain, values of 2 points, 1 point, and 0 points for activities performed independently, with assist, and unable to perform, respectively. The ADL scale was administered to surviving patients over the telephone at 1 year after surgery. A cumulative ADL score of 12 represented a normal score. Those with a score less than 8 were considered severely impaired. ${ }^{19,20}$ Further details are provided in the Appendix E1.

\section{Outcomes}

The primary outcome of the 1-year follow-up study was death or disability; the latter was defined as a surviving patient with a modified Katz ADL score of less than $8 .{ }^{19,21}$ The secondary endpoints were a composite and individual major adverse cardiovascular events (MACE), which included nonfatal myocardial infarction or stroke, or death from any cause, through to 1 year after surgery. Myocardial infarction was defined according to the third universal definition ${ }^{22}$ through to 1 year (note: we did not include isolated elevated cardiac enzyme or troponin elevation in our diagnosis of myocardial infarction as we had used previously ${ }^{11}$ ). Stroke was defined by cerebral infarction or hemorrhage on computed tomography scan, or new neurologic signs lasting more than 24 hours, up to 30 days after surgery as described previously,,$^{11}$ and subsequently through to 1 year. All events required a copy of the documentation in the patients' medical record. Further details are provided in the Appendix E1.

\section{Statistical Analysis}

The ATACAS trial was designed to achieve $90 \%$ power to detect a clinically important reduction in the 30-day primary outcome of death and thrombotic events up to 30 days after surgery from $10 \%$ to $7 \% .{ }^{16}$ We did not estimate statistical power for the 1-year follow-up study but expected a comparable difference in the event rate ${ }^{23}$ and effect size for our 1-year primary outcome.

Continuous data are reported as mean and standard deviation; categorical data are reported as frequency and percentage. Wald tests for risk ratios constructed from binomial regression with a logarithmic link were used to compare categorical data, with results expressed as relative risks with $95 \%$ 
TABLE 2. One-year outcomes according to treatment group

\begin{tabular}{|c|c|c|c|c|c|}
\hline Outcome & Total missing, $\%$ & Tranexamic acid & Placebo & $\mathbf{R R}(95 \% \mathbf{C I}) *$ & $P$ value \\
\hline \multicolumn{6}{|l|}{ Primary outcome } \\
\hline Death or disability $\dagger$ & 2.7 & $84 / 2237(3.8)$ & $100 / 2270(4.4)$ & $0.85(0.64-1.13)$ & .27 \\
\hline \multicolumn{6}{|l|}{ Secondary outcomes at $1 \mathrm{y}_{\ddagger}^{\dagger}$} \\
\hline Composite MACE outcome & 1.5 & $325 / 2268(14.3)$ & $376 / 2293(16.4)$ & $0.87(0.76-1.00)$ & .053 \\
\hline Myocardial infarction & 1.6 & $239 / 2223(10.7)$ & $274 / 2252(12.2)$ & $0.88(0.75-1.04)$ & .14 \\
\hline Stroke & 1.6 & $45 / 2216(2.0)$ & $61 / 2239(2.7)$ & $0.75(0.51-1.09)$ & .13 \\
\hline Death & 1.6 & $68 / 2267(3.0)$ & $78 / 2289(3.4)$ & $0.88(0.64-1.21)$ & .43 \\
\hline
\end{tabular}

$R R$, Relative risk; $C I$, confidence interval; $M A C E$, major adverse cardiovascular events, consisting of myocardial infarction, stroke, or death from any cause. $*$ RRs from binary regression models with logarithmic link. †Disability is defined by a Katz activities of daily living score of less than 8 (ie, severe). $\ddagger$ Three patients in the tranexamic acid group and

4 patients in the placebo group had a myocardial infarction or stroke within 30 days or surgery; these data were included in the secondary outcome analysis.

confidence intervals. For the tranexamic acid comparisons, 2 models were fitted for each outcome: the first included an interaction term for the randomized tranexamic acid group only; the second included an interaction term with aspirin exposure. We anticipated some missing outcome data in this study and so we performed a sensitivity analysis, adjusting for predictors of missing data. We evaluated the association between perioperative blood transfusion and 1-year disability-free survival and MACE, as well as between perioperative seizures and 1-year disability-free survival and MACE; each including multivariable adjustment for tranexamic acid and aspirin exposure, EuroSCORE, and open chamber surgery. All $P$ values are 2-sided and not adjusted for multiple comparisons.

\section{RESULTS}

\section{Patient Enrollment and Follow-up}

Between March 2006 and October 2015, we enrolled and randomly assigned patients to receive tranexamic acid (2329 patients) or placebo (2333 patients) in 31 centers in 7 countries (for details, see the Appendix E1). Of 4633 patients eligible for analysis at 30 days, 77 $(1.6 \%)$ were excluded from the 1-year analysis of our primary outcome because of loss to follow-up or other reasons, and disability scores were missing for a further $49(1.0 \%)$ patients (Figure 1). We had some relevant secondary outcome data for 7 of the 74 excluded patients, 3 of whom received tranexamic acid and 4 received placebo (Figure 1). The patient and perioperative baseline characteristics for the 1-year cohort are presented in Table 1. Patients had 1 or more risk factors for surgery; $83 \%$ of the patients were men, the mean \pm standard deviation age was $67 \pm 10$ years, and $21 \%$ underwent combined coronary artery-valvular surgery. There were no significant differences at baseline among the 2 groups. There were some minor differences in baseline characteristics when we compared those included in the 1 -year analysis and those with missing primary outcome data (Tables E1 and E2).

\section{Primary Outcome}

Of 4630 eligible patients, 4556 (98.4\%) had 1-year outcome data collected (Table 2 and Figure 1). The rate of death or disability at 1 year was $3.8 \%$ in the tranexamic acid group and $4.4 \%$ in the placebo group $(P=.27)$. There was no statistically significant differential effect of tranexamic acid according to aspirin exposure at the time of surgery (interaction $P=.073$ ). The rate of death or disability at 1 year was $3.3 \%$ in the tranexamic acid group and $4.7 \%$ in the placebo group in those who received aspirin before surgery $(P=.052)$, and $4.7 \%$ in the tranexamic acid group and $3.9 \%$ in the placebo group in

TABLE 3. RRs of 1-year outcomes for patients randomly assigned to tranexamic acid and according to aspirin exposure

\begin{tabular}{|c|c|c|c|c|c|}
\hline \multirow[b]{2}{*}{ Outcome } & \multicolumn{2}{|c|}{$\begin{array}{l}\text { Randomized to tranexamic acid and } \\
\text { exposed to aspirin }\end{array}$} & \multicolumn{2}{|c|}{$\begin{array}{l}\text { Randomized to tranexamic acid } \\
\text { and not exposed to aspirin }\end{array}$} & \multirow[b]{2}{*}{ Interaction $P$ valu } \\
\hline & RR $(95 \% \text { CI })^{*}$ & $P$ value & $\mathbf{R R}(95 \% \mathbf{C I})^{*}$ & $P$ value & \\
\hline \multicolumn{6}{|l|}{ Primary outcome } \\
\hline Death or disability $\dagger$ & $0.70(0.49-1.00)$ & .052 & $1.21(0.75-1.94)$ & .44 & .073 \\
\hline \multicolumn{6}{|l|}{ Secondary outcomes } \\
\hline Composite MACE outcome & $0.85(0.71-1.01)$ & .062 & $0.92(0.74-1.15)$ & .45 & .57 \\
\hline Myocardial infarction & $0.86(0.69-1.06)$ & .15 & $0.93(0.72-1.20)$ & .58 & .62 \\
\hline Stroke & $0.75(0.48-1.18)$ & .21 & $0.74(0.36-1.49)$ & .39 & .97 \\
\hline Death & $0.75(0.51-1.12)$ & .17 & $1.18(0.68-2.04)$ & .55 & .20 \\
\hline
\end{tabular}

RR, Relative risk; $C I$, confidence interval; $M A C E$, major adverse cardiovascular events, consisting of myocardial infarction, stroke, or death from any cause. $*$ RRs from binary regression models with logarithmic link. The models include an interaction term between tranexamic acid group and actual aspirin exposure. $\dagger$ Disability is defined by a Katz activities of daily living score of less than 8 (ie, severe). 


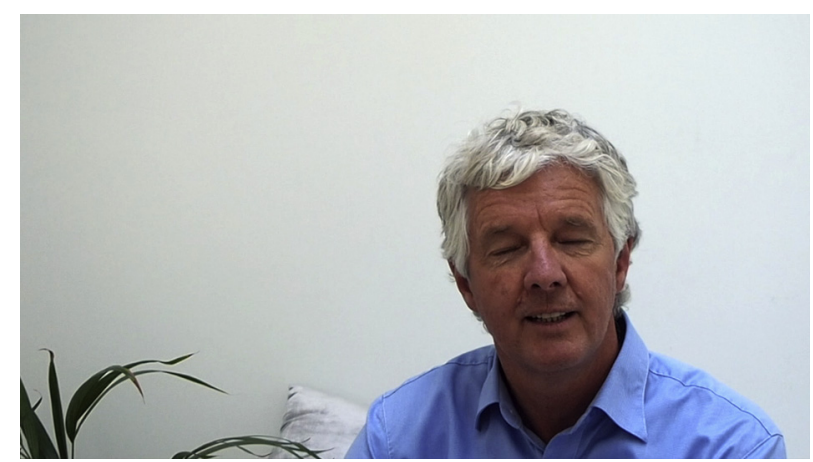

VIDEO 1. The lead author, Dr Paul Myles, discusses the overall results and clinical implications of the trial. Video available at: https://www.jtcvs.org/ article/S0022-5223(18)32779-X/fulltext.

those who did not receive aspirin before surgery $(P=.44)$ (Table 3 and Video 1). The effect of tranexamic acid on the risk of death or disability was consistent across subgroups $(P>.05$ for all interactions) (Figure 2$)$.

\section{Secondary Outcomes}

The rate of MACE up to 1 year after surgery was $14.3 \%$ in the tranexamic acid group and $16.4 \%$ in the placebo group $(P=.053)$ (Table 2 and Figure E1). The rate of MACE did not significantly differ across prespecified subgroups when we compared tranexamic acid and placebo (Figure 3). The 1 -year rate of nonfatal myocardial infarction was $10.7 \%$ in the tranexamic acid group and $12.2 \%$ in the placebo group $(P=.14)$. The 1 -year rate of stroke was $2.0 \%$ in the tranexamic acid group and $2.7 \%$ in the placebo group $(P=.13)$. The 1 -year mortality rate was $3.0 \%$ in the tranexamic acid group and $3.4 \%$ in the placebo group $(P=.43)$.

If we include the additional myocardial infarction events diagnosed only with marked cardiac enzyme or troponin elevation in the 30 days after surgery, at 1 year there were more myocardial infarctions in the placebo group, 413 $(18.4 \%)$ versus $438(19.3 \%)$, but this was not statistically significant, relative risk 0.95 ( $95 \%$ confidence interval, 0.84-1.08); $P=.44$.

Tables E3 and E4 show the results of comparisons adjusted for predictors of missing values for the effect of tranexamic acid, and after accounting for aspirin exposure, on the risk of death or disability, respectively. These were consistent with the unadjusted results, but with a significant reduction in the incidence of MACE (adjusted $P=.011$ ) at 1 year in favor of tranexamic acid.

There was no evidence for an interaction between tranexamic acid and aspirin exposure at the time of surgery for the secondary outcomes (Table 3). There was a significant association between exposure to blood transfusion at the time of surgery with both disability-free survival and MACE (both adjusted $P<.001$ ), and for perioperative seizures with MACE (adjusted $P<.001$ ), but not with disability-free survival (Table 4).
There were no significant differences in the rates of study outcomes when we compared the 2 different doses of tranexamic acid used in this study $(50 \mathrm{mg}$ per kilogram or $100 \mathrm{mg}$ per kilogram (Table E5).

\section{DISCUSSION}

This international trial comparing 1-year outcomes in patients undergoing coronary artery surgery aimed to assess long-term effects of tranexamic acid. At 1 year, patients receiving tranexamic acid did not have a lower rate of death or disability. Although we did not identify a significant interaction effect in those treated or not treated with aspirin on the day of their surgery, the $P$ value of this test for interaction $(P=.073)$ and the secondary test for the effect of tranexamic acid in those exposed to aspirin on the day of surgery $(P=.052)$ suggest a possible beneficial effect that was missed. This could be a type II error and those receiving tranexamic acid may have had a disability-free survival benefit if they were receiving aspirin on the day of surgery. This has direct relevance to the majority of patients undergoing coronary artery surgery, because a high proportion now receive aspirin up until the day of surgery.

At least one third of all cardiac surgical patients receive allogeneic blood transfusion. ${ }^{24,25}$ Transfusions are believed to increase the risk of septic and thrombotic complications after cardiac surgery, leading to greater risk of late deaths and disability. ${ }^{24,26}$ Antifibrinolytic therapy has become a standard of care to reduce bleeding and transfusion requirements in this setting. ${ }^{1,8,11}$ However, several procoagulant drugs used to prevent bleeding in cardiac surgery have been found to increase the risk of thrombosis and MACE, ${ }^{2-5,27-30}$ but we previously showed that tranexamic acid provides clinically important reductions in bleeding complications and transfusion without thrombotic risk. ${ }^{11}$ The differences in rates of commencement of aspirin within 24 hours of surgery probably reflects the lower rate of bleeding complications in the placebo group; this might increase the risk of early graft thrombosis and subsequent myocardial infarction.

Although we could not identify a reduction in thrombotic events in our earlier 30-day analysis, on post hoc testing when restricting the definition of myocardial infarction to the third universal definition, ${ }^{22}$ tranexamic acid was associated with a reduction in risk of myocardial infarction (relative risk $0.84 ; P=.045$ ). In this current study, we found a nonsignificant reduction in the composite endpoint that included myocardial infarction, stroke, and death. These possible beneficial effects of tranexamic acid might be secondary to less bleeding (supply-demand mismatch) or reduced exposure to transfusions at the time of surgery. ${ }^{11} \mathrm{~A}$ further possible explanation is that tranexamic acid has 


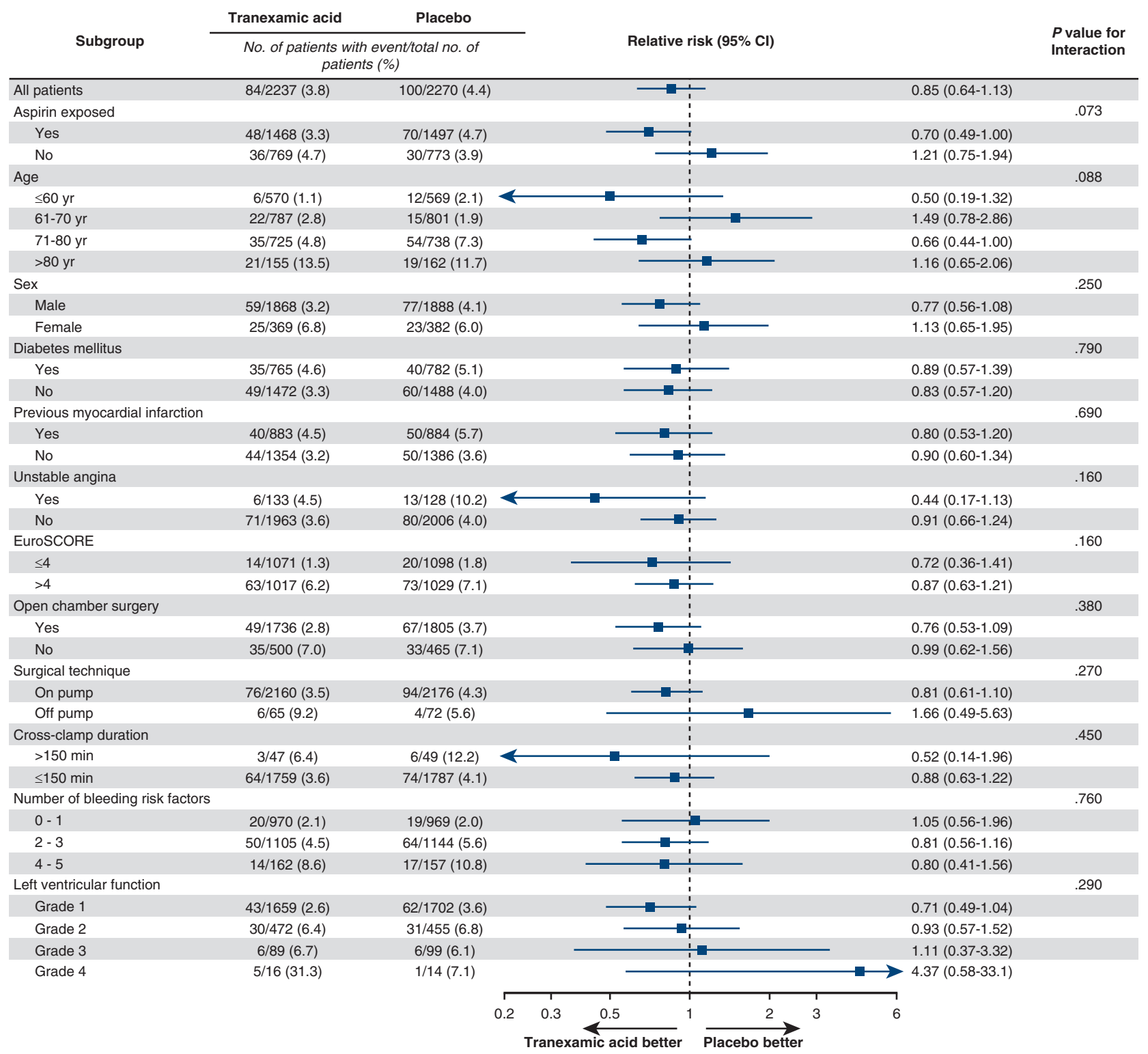

FIGURE 2. The risk for the primary outcome (death or disability) associated with tranexamic acid in prespecified subgroups, expressed as relative risk $(95 \%$ confidence interval $[C I])$.

immune modulatory effects that reduced inflammation leading to poor long-term recovery. ${ }^{31}$

\section{Study Limitations}

We used the Katz ADL scale, a measure of functional impairment, to identify patients with severe disability. However, disability encompasses more than functional impairment. ${ }^{32}$ The World Health Organization Disability Assessment Schedule 2.0 has been validated in the surgical setting, and we would recommend it as a preferable measure of disability in future perioperative studies. ${ }^{33}$ Our 1 -year follow-up study had some $(<3 \%)$ missing outcome data. We did not measure disability (Katz ADLs) scores preoperatively and so we cannot be sure how much of the disability measured at 1 year was pre-existing. However, in view of the comparable functional and health status scores, and comorbidities, reported at baseline, it is unlikely there was any imbalance in rates of baseline disability. Some of the statistically significant findings may be exposed to type I error because of multiple testing.

In conclusion, in this follow-up study, we found that tranexamic acid did not reduce the rate of death or disability up to 1 year after coronary artery surgery. 


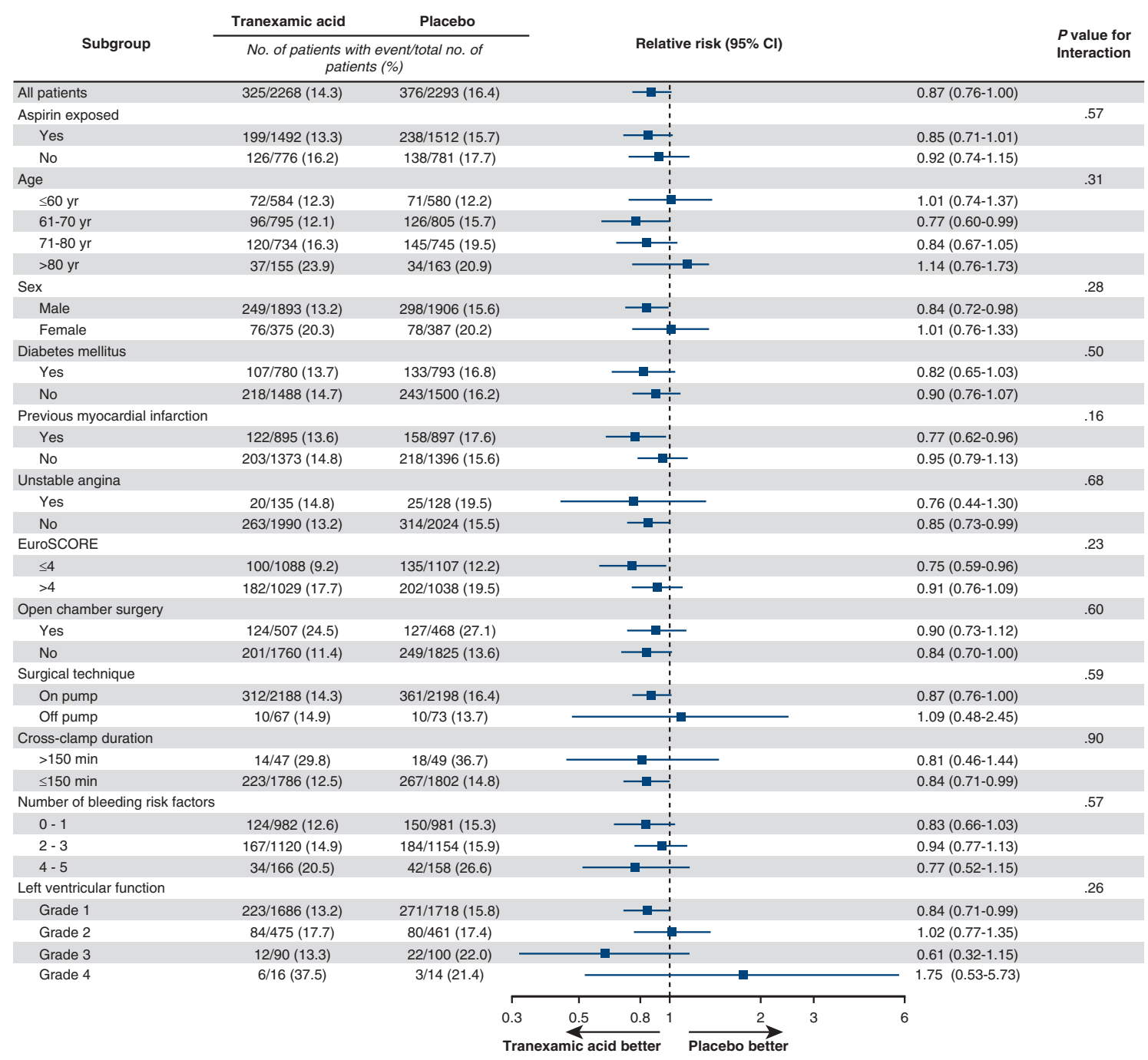

FIGURE 3. The risk for major adverse cardiovascular events (myocardial infarction, stroke, or death) associated with tranexamic acid in selected subgroups, expressed as relative risk $(95 \%$ confidence interval $[C I])$.

We suggest further mechanistic investigations on the deleterious effects of blood transfusions and possible beneficial effects of tranexamic acid on late cardiovascular events.

\section{Conflict of Interest Statement}

Bayer Pharma provided the aspirin and matched placebo tablets used in the study. All other authors have nothing to disclose with regard to commercial support.

TABLE 4. RRs of 1-year outcomes for patients who had a perioperative seizure or blood transfusion

\begin{tabular}{lcccccc}
\hline \multicolumn{1}{c}{ Outcome } & No seizure & Seizure & RR $^{*}(\mathbf{9 5} \% \mathbf{C I})$ & $\boldsymbol{P}$ value & Adjusted RR $\dagger(\mathbf{9 5} \% \mathbf{C I})$ & $\boldsymbol{P}$ value \\
\hline Death or disability $\ddagger$ & $182 / 4491(4.1)$ & $2 / 16(12.5)$ & $3.08(0.84-11.4)$ & .091 & $2.37(0.64,8.74)$ & .19 \\
Composite MACE outcome & $693 / 4544(15.2)$ & $8 / 17(47.1)$ & $3.09(1.86-5.13)$ & $<.001$ & $2.48(1.42,4.32)$ & .001 \\
\hline
\end{tabular}

(b) Perioperative blood transfusion (red cells, platelets, or fresh-frozen plasma) up to hospital discharge

\begin{tabular}{lcccccc}
\hline \multicolumn{1}{c}{ Outcome } & No transfusion & Transfusion & RR* (95\% CI) $^{*} \boldsymbol{P}$ value & Adjusted RR $\dagger(95 \%$ CI $)$ & $\boldsymbol{P}$ value \\
\hline Death or disability $\ddagger$ & $42 / 2418(1.7)$ & $142 / 2089(6.8)$ & $3.91(2.79-5.49)$ & $<.001$ & $2.69(1.89-3.83)$ & $<.001$ \\
Composite MACE outcome & $277 / 2443(11.3)$ & $424 / 2118(20.0)$ & $1.77(1.54-2.03)$ & $<.001$ & $1.41(1.21-1.65)$ & $<.001$ \\
\hline
\end{tabular}

$R R$, Relative risk; $C I$, confidence interval; $M A C E$, major adverse cardiovascular events, consisting of myocardial infarction, stroke, or death from any cause. * RRs from binary

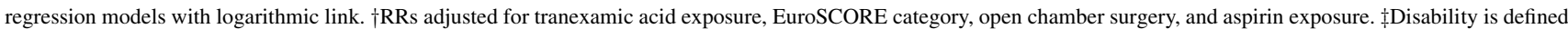
by a Katz activities of daily living score of less than 8 (ie, severe). 
The authors thank Adam Meehan for data management and Professors Andrew Tonkin, Henry Krum, and all members of the committees overseeing the trial, as well as the Australian and New Zealand College of Anaesthetists Clinical Trials Network.

\section{References}

1. Henry DA, Carless PA, Moxey AJ, O'Connell D, Stokes BJ, Fergusson DA, et al. Anti-fibrinolytic use for minimising perioperative allogeneic blood transfusion. Cochrane Database Syst Rev. 2011;CD001886.

2. Mangano DT, Tudor IC, Dietzel C. The risk associated with aprotinin in cardiac surgery. N Engl J Med. 2006;354:353-65.

3. Levi M, Cromheecke ME, de Jonge E, Prins MH, de Mol BJ, Briet E, et al. Pharmacological strategies to decrease excessive blood loss in cardiac surgery: a meta-analysis of clinically relevant endpoints. Lancet. 1999;354:1940-7.

4. Ponschab M, Landoni G, Biondi-Zoccai G, Bignami E, Frati E, Nicolotti D, et al. Recombinant activated factor VII increases stroke in cardiac surgery: a metaanalysis. J Cardiothorac Vasc Anesth. 2011;25:804-10.

5. Mangano DT, Miao Y, Vuylsteke A, Tudor IC, Juneja R, Filipescu D, et al. Mortality associated with aprotinin during 5 years following coronary artery bypass graft surgery. JAMA. 2007;297:471-9.

6. Ngaage DL, Bland JM. Lessons from aprotinin: is the routine use and inconsistent dosing of tranexamic acid prudent? Meta-analysis of randomised and large matched observational studies. Eur J Cardiothorac Surg. 2010;37:1375-83.

7. Mikkola R, Gunn J, Heikkinen J, Wistbacka JO, Teittinen K, Kuttila K, et al. Use of blood products and risk of stroke after coronary artery bypass surgery. Blood Transfus. 2012;10:490-501.

8. Ferraris VA, Brown JR, Despotis GJ, Hammon JW, Reece TB, Saha SP, et al. 2011 update to the Society of Thoracic Surgeons and the Society of Cardiovascular Anesthesiologists blood conservation clinical practice guidelines. Ann Thorac Surg. 2011;91:944-82.

9. Gaudino M, Antoniades C, Benedetto U, Deb S, Di Franco A, Di Giammarco G, et al. Mechanisms, consequences, and prevention of coronary graft failure. Circulation. 2017;136:1749-64.

10. Almassi GH, Carr BM, Bishawi M, Shroyer AL, Quin JA, Hattler B, et al. Resident versus attending surgeon graft patency and clinical outcomes in on- versus off-pump coronary artery bypass surgery. J Thorac Cardiovasc Surg. 2015;150: 1428-35. 37.e1; discussion 35-7.

11. Myles PS, Smith JA, Forbes A, Silbert B, Jayarajah M, Painter T, et al. Tranexamic acid in coronary artery surgery. $N$ Engl J Med. 2017;376:136-48.

12. Forman DE, Arena R, Boxer R, Dolansky MA, Eng JJ, Fleg JL, et al. Prioritizing functional capacity as a principal end point for therapies oriented to older adults with cardiovascular disease: a scientific statement for healthcare professionals from the American Heart Association. Circulation. 2017;135:e894-918.

13. Kalkman CJ, Kappen TH. Patient-centered endpoints for perioperative outcomes research. Anesthesiology. 2015;122:481-3.

14. Rumsfeld JS, Alexander KP, Goff DC Jr, Graham MM, Ho PM, Masoudi FA, et al. Cardiovascular health: the importance of measuring patient-reported health status: a scientific statement from the American Heart Association. Circulation. 2013; 127:2233-49.

15. Newman AB, Arnold AM, Naydeck BL, Fried LP, Burke GL, Enright P, et al "Successful aging": effect of subclinical cardiovascular disease. Arch Intern Med. 2003;163:2315-22.

16. Myles P, Smith J, Knight J, Cooper D, Silbert B, McNeil J, et al. Aspirin and Tranexamic Acid for Coronary Artery Surgery (ATACAS) Trial: rationale and design. Am Heart J. 2008;155:224-30.
17. Myles PS, Smith JA, Forbes A, Silbert B, Jayarajah M, Painter T, et al. Stopping vs. continuing aspirin before coronary artery surgery. $N$ Engl J Med. 2016;374: 728-37.

18. Dowd NP, Karski JM, Cheng DC, Carroll JA, Lin Y, James RL, Butterworth J, et al. Pharmacokinetics of tranexamic acid during cardiopulmonary bypass. Anesthesiology. 2002;97:390-9.

19. Katz S, Ford AB, Moskowitz RW, Jackson BA, Jaffe MW. Studies of illness in the aged. The index of Adl: a standardized measure of biological and psychosocial function. JAMA. 1963;185:914-9.

20. Katz S, Downs TD, Cash HR, Grotz RC. Progress in development of the index of ADL. Gerontologist. 1970;10:20-30.

21. Williams MR, Wellner RB, Hartnett EA, Thornton B, Kavarana MN, Mahapatra R, et al. Long-term survival and quality of life in cardiac surgical patients with prolonged intensive care unit length of stay. Ann Thorac Surg. 2002; $73: 1472-8$

22. Thygesen K, Alpert JS, Jaffe AS, Simoons ML, Chaitman BR, White HD, et al. Third universal definition of myocardial infarction. Circulation. 2012;126: 2020-35.

23. Shahian DM, Heatley GJ, Westcott GA. Relationship of hospital size, case volume, and cost for coronary artery bypass surgery: analysis of 12,774 patients operated on in Massachusetts during fiscal years 1995 and 1996. J Thorac Cardiovasc Surg. 2001;122:53-64.

24. Koch CG, Li L, Duncan AI, Mihaljevic T, Cosgrove DM, Loop FD, et al Morbidity and mortality risk associated with red blood cell and blood component transfusion in isolated coronary artery bypass grafting. Crit Care Med. 2006:34:1608-16.

25. LaPar DJ, Hawkins RB, McMurry TL, Isbell JM, Rich JB, Speir AM, et al. Preoperative anemia versus blood transfusion: which is the culprit for worse outcomes in cardiac surgery? J Thorac Cardiovasc Surg. 2018;156:66-74.e2

26. Kuduvalli M, Oo AY, Newall N, Grayson AD, Jackson M, Desmond MJ, et al Effect of peri-operative red blood cell transfusion on 30-day and 1-year mortality following coronary artery bypass surgery. Eur J Cardiothorac Surg. 2005;27: 592-8.

27. Risch A, Dorscheid E, Stein G, Seyfert UT, Grundmann U. The effect of aprotinin and tranexamic acid on fibrinolysis and thrombin generation during cardiopulmonary bypass [in German]. Anaesthesist. 2000;49:279-85.

28. Dentz ME, Slaughter TF, Mark JB. Early thrombus formation on heparin-bonded pulmonary artery catheters in patients receiving epsilon aminocaproic acid. Anesthesiology. 1995;82:583-6.

29. Garg J, Pinnamaneni S, Aronow WS, Ahmad H. ST elevation myocardial infarction after tranexamic acid: first reported case in the United States. Am J Ther 2014;21:e221-4.

30. Stief TW. Tranexamic acid triggers thrombin generation. Hemost Lab. 2009;2 73-82.

31. Draxler DF, Medcalf RL. The fibrinolytic system-more than fibrinolysis? Transfus Med Rev. 2015;29:102-9.

32. World Health Organization. International Classification of Functioning Disability and Health. Geneva: World Health Organization; 2001:1-299.

33. Shulman MA, Myles PS, Chan MT, McIlroy DR, Wallace S, Ponsford J. Measurement of disability-free survival after surgery. Anesthesiology. 2015;122: 524-36.

Key Words: anesthesia, antifibrinolytic, antiplatelet, disability-free survival, major adverse cardiac events, outcomes 


\section{APPENDIX E1}

\section{List of Investigators and Committees in the ATACAS}

Trial

Steering Committee: Paul Myles (chair), Julian Smith, D. James Cooper, Brendan Silbert, John McNeil, Silvana Marasco, Donald Esmore (deceased), Henry Krum (until July 2013)

Data Safety Monitoring Board: A. Tonkin (chair), B. Buxton, S. Heritier, A. Merry, D. Liew

Data Quality Committee: J. McNeil, A. Forbes, D. J. Cooper, S. Wallace, A. Meehan

Funding: National Health and Medical Research Council of Australia (NHMRC, ID 334015 and 1009203); the Australian and New Zealand College of Anaesthetists; and the UK National Institute of Health Research.

Study Sponsor (except UK): Alfred Health

UK Sponsor: Plymouth NHS trust

\section{List of principal investigators and study coordinators \\ Australia}

Alfred Hospital: P. Myles, S. Wallace, W. Galagher, C. Farrington, A. Ditoro, L. Wutzlhofer; Austin Hospital: D. Story, P. Peyton, S. Baulch, S. Sidiropoulos; Canberra Hospital: D. Potgieter; Flinders Medical Centre: R. A. Baker, B. Pesudovs; Fremantle Hospital: E. O'Loughlin. J. Wells, P. Coutts; Geelong Hospital: S. Bolsin, C. Osborne, K. Ives; Monash Medical Centre: J. Smith, A. Hulley; Royal Adelaide Hospital: G. Christie-Taylor, T. Painter, S. Lang, H. Mackay; Royal Perth Hospital: C. Cokis, S. March; Royal Prince Alfred: P. G. Bannon, C. Wong, L. Turner; St Vincent's Hospital (Vic): D. Scott,
B. Silbert, S. Said, P. Corcoran; Wakefield Hospital: T. Painter, L. de Prinse

\section{Canada}

Institut universitaire de cardiologie et de pneumology de Québec - Université Laval: J. S. Bussières, N. Gagné; Hamilton General: A. Lamy, L. Semelhago

\section{Hong Kong}

Prince of Wales Hospital: M. T. V. Chan, M. Underwood, G. S. Y. Choi, B. Fung

\section{Italy}

San Raffaele Scientific Institute, Milan, Italy: G. Landoni, R. Lembo, F. Monaco; Azienda Ospedaliera Senese Siena: F. Simeone, D. Marianello; Azienda Ospedaliera Mater Domini - Catanzaro: G. Alvaro, G. De Vuono

\section{Netherlands}

University Medical Center Utrecht: D. van Dijk, J. Dieleman, S. Numan

\section{New Zealand}

Auckland Hospital: S. McGuinness, R. Parke, P. Raudkivi, E. Gilder; Waikato Hospital: K. Byrne, J. Dunning, J. Termaat, G. Mans

\section{United Kingdom}

South West Cardiac Centre, Derriford Hospital, and Plymouth NHS Trust (UK Coordinating Center): M. Jayarajah, J. Alderton, D. Waugh; Bristol Royal Infirmary: M. J. Platt; Essex Cardiothoracic Centre: A. Pai, A. Sevillano; Golden Jubilee National Hospital: A. Lal, C. Sinclair; Kings College Hospital: G. Kunst, A. Knighton, G. M. Cubas; Lancashire Cardiac Centre: P. Saravanan, R. Millner, V. Vasudevan; Hospitals of Coventry and Warwickshire: M. Patteril, E. Lopez; Nottingham University Hospitals: R. Basu, J. Lu

List of Ethics Committees/Institutional Review Boards

\begin{tabular}{|c|c|c|}
\hline Site & Ethics approval & Approval Number \\
\hline Alfred Hospital & $\begin{array}{l}\text { Alfred Hospital Ethics Committee, Alfred Hospital, } \\
\text { Commercial Road, Prahran 3181, Australia }\end{array}$ & $11 / 05$ \\
\hline Austin Health & $\begin{array}{l}\text { Human Research Ethics Committee, Office for } \\
\text { Research, Austin Hospital, Level } 6 \text { HSB,145 Studley } \\
\text { Road, Heidelberg, Victoria, Australia } 3084\end{array}$ & H2005/02261 \\
\hline St Vincent's Hospital Melbourne & $\begin{array}{l}\text { Research and Grants Unit, St Vincent's Hospital, } 41 \\
\text { Victoria Parade, Melbourne } 3004\end{array}$ & $040 / 05$ \\
\hline Monash Medical Centre & $\begin{array}{l}\text { Human Research Ethics Committee, Monash Medical } \\
\text { Centre, } 246 \text { Clayton Road, Clayton, Victoria, } \\
\text { Australia } 3168\end{array}$ & 05079B \\
\hline Geelong Hospital & $\begin{array}{l}\text { The Research and Ethics advisory committee, Barwon } \\
\text { Health }\end{array}$ & 14001 \\
\hline Royal Prince Alfred & $\begin{array}{l}\text { Ethics Review committee, Sydney South West Area } \\
\text { Health Service, Research Development Office, Level } \\
\text { 8, Building 14, Royal Prince Alfred Hospital, } \\
\text { Camperdown, NSW, } 2050\end{array}$ & $\mathrm{X} 11-0318$ \\
\hline
\end{tabular}

(Continued) 


\begin{tabular}{|c|c|c|}
\hline Site & Ethics approval & Approval Number \\
\hline Flinders Medical Centre & $\begin{array}{l}\text { Flinders Medical Centre, Flinders Clinical Research } \\
\text { Ethics Committee, Flinders Clinical Drug Trials } \\
\text { Committee, Flinders Medical Centre, The Flats G5 - } \\
\text { Rooms } 3 \text { and } 4 \text { Flinders Drive, Bedford Park South, } \\
\text { Australia } 5042\end{array}$ & 80.067 \\
\hline St Vincent's Sydney & $\begin{array}{l}\text { St Vincent's Hospital HREC, } 390 \text { Victoria Street, } \\
\text { Darlinghurst NSW } 2010\end{array}$ & $07 / \mathrm{SVH} / 26$ \\
\hline Waikato Hospital & $\begin{array}{l}\text { Health and Disability Ethics Committee, Northern Y } \\
\text { Regional Ethics Committee, c/o Ministry of Health, } \\
\text { Level 3, Bridgewater Building, } 130 \text { Grantham St, } \\
\text { Hamilton } 3204\end{array}$ & NTY//11/10/096/AM06 \\
\hline Auckland Hospital & $\begin{array}{l}\text { Health and Disability Ethics Committee, Northern Y } \\
\text { Regional Ethics Committee, c/o Ministry of Health, } \\
\text { Level 3, Bridgewater Building, } 130 \text { Grantham St, } \\
\text { Hamilton } 3204\end{array}$ & NTY//11/10/096/AM06 \\
\hline Prince of Wales Hong Kong & $\begin{array}{l}\text { Joint Chinese University of Hong Kong - New } \\
\text { Territories East Cluster Clinical Research Ethics } \\
\text { Committee, Flat 3C, Block B, Staff Quarters, Prince } \\
\text { of Wales Hospital, Shatin, Hong Kong }\end{array}$ & CRE-2009.403-T \\
\hline Canberra Hospital & $\begin{array}{l}\text { ACT Government Health Directorate, Human } \\
\text { Research Ethics Committee, Building } 10 \text { Level } 6 \\
\text { Canberra Hospital, Garran ACT } 2605\end{array}$ & ETH.11.09.948 \\
\hline Royal Adelaide Hospital & $\begin{array}{l}\text { Research Ethics Committee, Royal Adelaide Hospital, } \\
\text { North Terrace, Adelaide, SA } 5000\end{array}$ & 61028 \\
\hline Royal Perth Hospital & $\begin{array}{l}\text { Royal Perth Hospital Ethics Committee, Royal Perth } \\
\text { Hospital - Level 4, Kirkman House, } 10 \text { Murray Street, } \\
\text { PERTH WA } 6000\end{array}$ & $2008 / 042$ \\
\hline Fremantle Hospital & $\begin{array}{l}\text { Human research ethics committee, c/- Fremantle } \\
\text { Hospital and Health Service, Alma Street Fremantle } \\
\text { WA }\end{array}$ & EC 2008/042 \\
\hline Hamilton General & $\begin{array}{l}\text { Research Ethics Board, Hamilton Health Sciences, } 293 \\
\text { Wellington St N, Suite 102, Hamilton ON L8L 8E7 }\end{array}$ & $11-605$ \\
\hline $\begin{array}{l}\text { Institut universitaire de cardiologie et de } \\
\text { pneumology de Québec }\end{array}$ & $\begin{array}{l}\text { Comite d'ethique de la recherche de l'institut } \\
\text { universitaire de cardiologie et de pneumologie de } \\
\text { Quebec (Hopital Laval) 2725, chemin Sainte-Foy, } \\
\text { Quebec, Canada G1V 4G5 }\end{array}$ & 20356 \\
\hline San Raffaele Scientific Institute, Milan, Italy & $\begin{array}{l}\text { IL COMITATO ETICO dell'Ospedale San Raffaele - } \\
\text { Istituto di Ricovero e Cura a Carattere Scientifico, Via } \\
\text { Olgettina, } 6030132\end{array}$ & $2013 / 70$ \\
\hline Wakefield Hospital & $\begin{array}{l}\text { Research Ethics Committee, Royal Adelaide Hospital, } \\
\text { North Terrace, Adelaide, SA } 5000\end{array}$ & 61028 \\
\hline Azienda Ospedaliera Senese - Siena, Italy & $\begin{array}{l}\text { Azienda Ospedaliera Universitaria Senese, C/o } \\
\text { Farmacia Ospedaliero Universitaria-Viale Bracci, } \\
16 \text { - } 53100 \text { Siena }\end{array}$ & $2013 / 70$ \\
\hline Azienda Ospedaliera Mater Domini, Catanzaro & $\begin{array}{l}\text { Comitato Etico Azienda Ospedaliera Universitaria } \\
\text { “Mater Domini” Viale Europa - Loc. Germaneto } \\
88100 \text { CatanZaro }\end{array}$ & $2013 / 70$ \\
\hline University Medical Center Utrecht & $\begin{array}{l}\text { Medical Research Ethics Committee (METC), UMC } \\
\text { Utrecht }\end{array}$ & $\mathrm{SL} / \mathrm{rc} / 14 / 009180$ \\
\hline $\begin{array}{l}\text { United Kingdom MHRA adoption } \\
\text { approval number } 13605 / 0207 / 001-0001\end{array}$ & $\begin{array}{l}\text { EudraCT number 2009-015013-46 IRAS ID } 28150 \\
\text { REC No. 09/H0206/44 }\end{array}$ & \\
\hline
\end{tabular}




\begin{tabular}{|c|c|c|}
\hline Site & Ethics approval & Approval Number \\
\hline Golden Jubilee National Hospital & $\begin{array}{l}\text { National Waiting Times Centre Board, Golden Jubilee } \\
\text { Hospital, Beardmore Street, Clydebank G81 4HX }\end{array}$ & 14/ANAES/01 \\
\hline Bristol Royal Infirmary & $\begin{array}{l}\text { REC, North Somerset \& South Bristol Research } \\
\text { Ethics Committee Research and Development, } \\
\text { Bristol. }\end{array}$ & 07/H0106/140 \\
\hline Hospitals of Coventry and Warwickshire & $\begin{array}{l}\text { Research, Development and Innovation Department, } \\
\text { University Hospitals Coventry and Warwickshire } \\
\text { NHS Trust }\end{array}$ & 09/H0206/44 \\
\hline $\begin{array}{l}\text { South West Cardiac Centre, Derriford Hospital, } \\
\text { and Plymouth NHS Trust }\end{array}$ & $\begin{array}{l}\text { South West Research Ethics Committee, Royal Devon } \\
\text { and Exeter Hospital (Heavitree) Gladstone Road, } \\
\text { Exeter EX1 2ED, UK }\end{array}$ & 09/H0206/44 \\
\hline Kings College London & $\begin{array}{l}\text { The Research Office, Kings College Hospital NHS } \\
\text { Foundation Trust, First Floor, } 161 \text { Denmark Hill, } \\
\text { London SE5 8EF, UK }\end{array}$ & 09/H0206/44 \\
\hline Essex Cardiothoracic Centre & $\begin{array}{l}\text { Research and Development Department, The Education } \\
\text { Centre - Basildon University Hospital, Nether Mayne, } \\
\text { Basildon, Essex SS16 5NL, UK }\end{array}$ & Research B515, UKCRN 8338 \\
\hline Nottingham University Hospital & $\begin{array}{l}\text { Research \& Innovation, Nottingham Health Science } \\
\text { Partners, C Floor, South Block, Queen's Medical Centre } \\
\text { Campus, Derby Road, Nottingham NG7 2UH, UK }\end{array}$ & 09/H0206/44 RD0605 \\
\hline Edinburgh Royal Infirmary & $\begin{array}{l}\text { University Hospitals Division, Queens Medical Research } \\
\text { Institute, } 47 \text { France Crescent, Edinburgh, EH16 4TJ, UK }\end{array}$ & 2010/R/AN/05 \\
\hline Lancashire Cardiac Centre & $\begin{array}{l}\text { Research and Development, Clinical Research Centre - } \\
\text { 2nd Floor, Area 5, Blackpool Victoria Hospital, } \\
\text { Whinney Heys Road, Blackpool, Lancashire FY3 } \\
\text { 8NR, UK }\end{array}$ & RD0605 \\
\hline
\end{tabular}

\section{Inclusion criteria}

1. Males and females, age 18 years and over

2. Written, informed consent

3. Elective coronary artery surgery (on-pump or off-pump)

4. Patient is at increased risk of major complications, defined by any of the following:

- Age $\geq 70$ years,

- Left ventricular impairment (fractional area change $<20 \%$, ejection fraction $<40 \%$, or at least moderate impairment on ventriculography),

- Concomitant valvular or aortic surgery,

- Left ventricular aneurysmectomy,

- Repeat cardiac surgery ("re-do"),

- Chronic obstructive pulmonary disease,

- Renal impairment (se. creatinine $>150 \mu \mathrm{mol} / \mathrm{L}$ or creatinine clearance $<45 \mathrm{~mL} / \mathrm{min}$ ),

- Obesity (body mass index $>25 \mathrm{~kg} / \mathrm{m}^{2}$ ),

- Pulmonary hypertension (mean pulmonary artery pressure $>25 \mathrm{~mm} \mathrm{Hg}$ ), or

- Peripheral vascular disease.

\section{Exclusion criteria}

1. Poor (English) language comprehension

2. Clinician preference for antifibrinolytic therapy

3. Urgent surgery for unstable coronary syndromes where for clinical reasons antiplatelet medication cannot be discontinued

4. Active peptic ulceration

5. Allergy or contraindication to aspirin or tranexamic acid

6. Aspirin therapy within 4 days of surgery

7. Warfarin or clopidogrel therapy within 7 days of surgery, or GIIb/IIIa antagonists within 24 hours of surgery

8. Thrombocytopenia or any other known history of bleeding disorder

9. Severe renal impairment (serum creatinine $>250 \mu \mathrm{mol} / \mathrm{l}$, or estimated creatinine clearance $<25 \mathrm{~mL} / \mathrm{min}$ )

10. Recent hematuria

11. Thromboembolic disease relating to: history of postoperative or spontaneous pulmonary embolism, spontaneous arterial thrombosis or familial hypercoagulability (eg, lupus anticoagulant, protein $\mathrm{C}$ deficiency)

12. Pregnancy 


\section{Inclusion criteria changes following aspirin arm completed (date July 25, 2013)}

- Allergy or contraindication to tranexamic acid

- Thrombocytopenia or any other known history of bleeding disorder for which antifibrinolytic therapy is considered by the surgeon or local investigators to be mandatory

\section{One-Year Study Outcome Definitions Primary Outcome}

A composite of death from any cause or physical disability defined as a modified Katz independent activities of daily living (ADL) index score of less than $8 .^{\mathrm{E} 1}$ Katz developed an index of independence in ADL to monitor the independence of chronically ill patients. The 6 activities used in this evaluation were related hierarchically. Any person functioning without supervision, direction, or actual personal assistant was considered to be functioning independently within any of the six categories.

Our Katz ADL index used a modified version of the scale from the original, which included 3 categories representing degrees of function for each of the 6 ADLs, to substituting point values. This has become a widely used modification. ${ }^{\mathrm{E} 2}$ For the 6 ADLs applied, each were assigned values of 2 points, 1 point, and 0 points for activities performed independently, with assist, and unable to perform, respectively.

The ADL scale was administered to surviving patients over the telephone at 1 year after surgery. The activities on which we based our assessment consisted of standing, toileting, bathing, walking, eating, and dressing. A cumulative ADL score of 12 represented a normal score. Those receiving scores between 8 and 12 were considered impaired, and those with a score less than 8 were considered severely impaired.

\section{Secondary Outcomes at 1-Year}

1. All-cause mortality

2. Myocardial infarction up to day-30: the presence of either a typical rise and gradual fall (troponin) or more rapid rise and fall (creatine kinase-muscle/brain) of biochemical markers of myocardial necrosis with at least 1 of the following:

- ischemic symptoms,

- development of pathologic Q waves on 2 adjacent leads on the electrocardiogram,

- electrocardiogram changes indicative of ischemia (ST-segment elevation or depression), or

- pathologic findings (autopsy) of an acute myocardial infarction.

In view of the difficulty of detecting ischemic chest pain in the early postoperative period, in addition to the aforementioned, a non-Q wave myocardial infarction will be defined by a cardiac enzyme elevation in isolated coronary artery bypass grafting (CABG) cases, using any of:

- troponin $\mathrm{I}>10 \mathrm{ng} / \mathrm{mL}$ at any time $>12$ hours postCABG,

- troponin $\mathrm{T}>4.0$ at $>12$ hours post-CABG, and

- creatine kinase-muscle/brain $>3$ times upper limit of normal at $>12$ hours post-CABG.

For the post-day 30, 1-year follow-up we required a copy of the documentation of a new myocardial infarction in the patients' medical record or confirmation via telephone contact with the patient's medical practitioner.

3. Stroke: Up to day-30 we required a diagnosis of cerebral infarction or hemorrhage on computed tomography scan or new neurologic signs (paralysis, weakness, or speech difficulties) lasting more than 24 hours or leading to earlier death. For the 1-year follow-up we required a

Activities of Daily Living Score

\begin{tabular}{llll}
\hline \multicolumn{1}{c}{ Activity } & Little or no difficulty $(=\mathbf{2}$ points $)$ & Some difficulty or with assistance (=1 point $)$ & Unable (=0 point) \\
\hline Moving in and out of a chair or bed & & \\
Using the toilet & \\
Bathing or showering & \\
Walking across a room & \\
Eating & \\
Dressing & \\
\hline
\end{tabular}


copy of the documentation of a new stroke in the patients' medical record or confirmation via telephone contact with the patient's medical practitioner.

4. Major adverse cardiovascular events: a postoperative diagnosis of a new myocardial infarction, stroke, or death (ie, a composite), each defined as previously.

\section{E-References}

E1. Katz S, Ford AB, Moskowitz RW, Jackson BA, Jaffe MW. Studies of illness in the aged. The index of ADL: a standardized measure of biological and psychosocial function. JAMA. 1963;185:914-9.

E2. Williams MR, Wellner RB, Hartnett EA, Thornton B, Kavarana MN Mahapatra R, et al. Long-term survival and quality of life in cardiac surgical patients with prolonged intensive care unit length of stay. Ann Thorac Surg. 2002 73:1472-8.

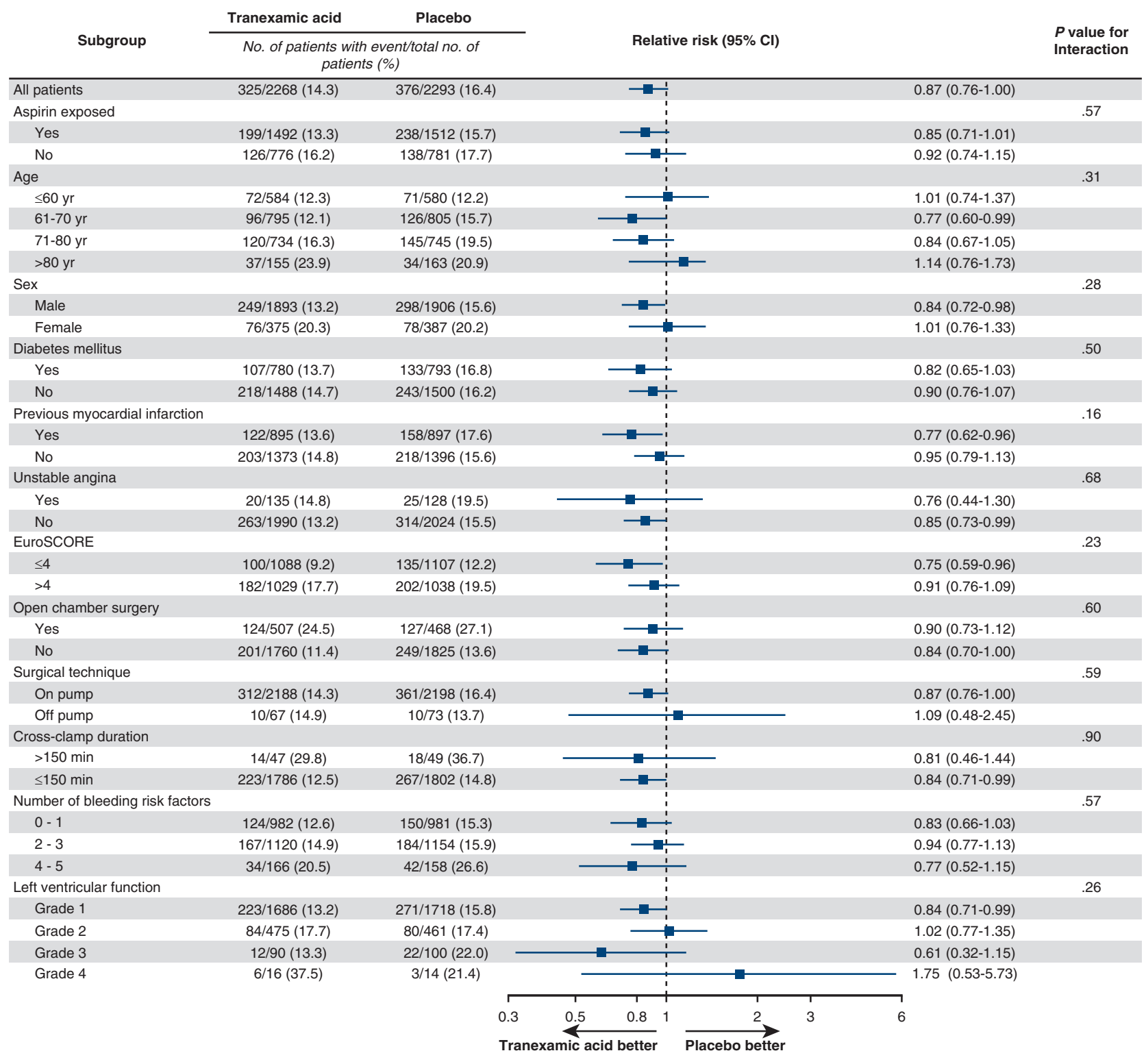

FIGURE E1. The risk for major adverse cardiovascular events (myocardial infarction, stroke, or death) associated with tranexamic acid in selected subgroups, expressed as relative risk $(95 \%$ confidence interval $[C I])$. 
TABLE E1. Details of patient enrolment numbers and follow-ups at each study center

\begin{tabular}{|c|c|c|c|c|c|}
\hline Center & No. enrolled & $\begin{array}{c}\text { No. eligible for analysis at } \\
1 \text { year } \\
\end{array}$ & $\begin{array}{l}\text { No. available for } \\
\text { analysis at } 1 \text { year }\end{array}$ & $\begin{array}{l}\text { No. from centers } \\
\text { not participating }\end{array}$ & $\begin{array}{c}\text { Patient withdrawn } \\
\text { before } 1 \text { year }\end{array}$ \\
\hline \multicolumn{6}{|l|}{ Australia } \\
\hline Alfred & 612 & 608 & 602 & - & 10 \\
\hline Austin & 150 & 150 & 147 & - & 3 \\
\hline Calvary Wakefield & 57 & 56 & 56 & - & 1 \\
\hline Canberra & 8 & 8 & 8 & - & 0 \\
\hline Royal Adelaide & 747 & 744 & 734 & - & 13 \\
\hline Royal Perth & 33 & 33 & 33 & - & 0 \\
\hline Freemantle & 77 & 76 & 76 & - & 1 \\
\hline St Vincent's, Vic. & 277 & 274 & 269 & - & 5 \\
\hline Monash MC & 334 & 331 & 331 & - & 3 \\
\hline Geelong & 241 & 241 & 230 & - & 11 \\
\hline Royal Prince Alfred & 111 & 111 & 107 & - & 4 \\
\hline Flinders & 140 & 136 & 136 & - & 4 \\
\hline St Vincent's, NSW & 1 & 1 & 0 & 1 & 0 \\
\hline \multicolumn{6}{|l|}{ New Zealand } \\
\hline Waikato & 259 & 258 & 256 & - & 3 \\
\hline Auckland & 320 & 319 & 314 & - & 6 \\
\hline \multicolumn{6}{|l|}{ Hong Kong } \\
\hline Prince of Wales & 264 & 263 & 263 & - & 1 \\
\hline Canada & & & & - & \\
\hline Hamilton & 89 & 88 & 88 & - & 1 \\
\hline Hôpital L Laval & 305 & 302 & 290 & - & 15 \\
\hline \multicolumn{6}{|l|}{ United Kingdom } \\
\hline Golden Jubilee & 51 & 50 & 50 & - & 1 \\
\hline Bristol & 3 & 3 & 3 & - & 0 \\
\hline Coventry & 20 & 20 & 20 & - & 0 \\
\hline Plymouth & 125 & 125 & 119 & - & 6 \\
\hline Kings & 40 & 39 & 39 & - & 1 \\
\hline Essex & 144 & 141 & 137 & - & 7 \\
\hline Trent & 5 & 5 & 5 & - & 0 \\
\hline Edinburgh & 2 & 2 & 0 & 2 & 0 \\
\hline Lancashire & 84 & 82 & 82 & - & 2 \\
\hline The Netherlands & & & & - & \\
\hline Utrecht Medical Center & 32 & 32 & 30 & - & 2 \\
\hline \multicolumn{6}{|l|}{ Italy } \\
\hline San Raffaele & 84 & 84 & 84 & - & 0 \\
\hline Sienna & 35 & 35 & 34 & - & 1 \\
\hline Azienda & 12 & 11 & 11 & - & 1 \\
\hline Total & 4662 & 4631 & 4557 & 3 & 102 \\
\hline
\end{tabular}


TABLE E2. Patient characteristics for those with and without missing disability or death outcomes

\begin{tabular}{|c|c|c|c|}
\hline Baseline characteristic & Not missing $(n=4507)$ & Missing $(n=123)$ & $P$ value \\
\hline Age, y & $67.0(9.6)$ & $62.1(11.7)$ & $<.001$ \\
\hline Weight, kg & $86.0(17.0)$ & $89.9(17.9)$ & .012 \\
\hline Male & $3756(83.3)$ & $103(83.7)$ & .91 \\
\hline $\begin{array}{l}\text { NYHA class } \\
1 \\
2 \\
3 \\
4\end{array}$ & $\begin{array}{c}862(19.1) \\
2306(51.2) \\
1222(27.1) \\
116(2.6)\end{array}$ & $\begin{array}{c}27(22.0) \\
63(51.2) \\
31(25.2) \\
2(1.6)\end{array}$ & .78 \\
\hline $\begin{array}{l}\text { ASA physical status } \\
2 \\
3 \\
4\end{array}$ & $\begin{array}{c}174(3.9) \\
2361(52.4) \\
1972(43.8)\end{array}$ & $\begin{array}{c}3(2.4) \\
66(53.7) \\
54(43.9)\end{array}$ & .72 \\
\hline $\begin{array}{l}\text { Left ventricular ejection fraction } \\
\qquad 50 \% \\
35 \%-50 \% \\
20 \%-34 \% \\
<20 \%\end{array}$ & $\begin{array}{c}3361(74.6) \\
927(20.6) \\
188(4.2) \\
30(0.7)\end{array}$ & $\begin{array}{c}84(68.3) \\
32(26.0) \\
6(4.9) \\
1(0.8)\end{array}$ & .47 \\
\hline EuroSCORE & $4.7(3.0)$ & $3.9(3.0)$ & .004 \\
\hline \multicolumn{4}{|l|}{ Pre-existing medical conditions } \\
\hline Diabetes status & $1547(34.3)$ & $57(46.3)$ & .006 \\
\hline Renal impairment & $336(7.5)$ & $7(5.7)$ & .46 \\
\hline Hypertension & $3570(79.2)$ & $97(78.9)$ & .93 \\
\hline Angina & $3086(68.5)$ & $76(61.8)$ & .12 \\
\hline Heart failure & $474(10.5)$ & $10(8.1)$ & .39 \\
\hline Myocardial infarction & $1767(39.2)$ & $56(45.5)$ & .16 \\
\hline Endocarditis & $8(0.2)$ & $0(0.0)$ & .64 \\
\hline Cerebrovascular disease & $439(9.7)$ & $8(6.5)$ & .23 \\
\hline Peripheral vascular disease & $458(10.2)$ & $7(5.7)$ & .10 \\
\hline Pulmonary hypertension & $233(5.2)$ & $6(4.9)$ & .89 \\
\hline Previous PTCA/stent & $114(2.5)$ & $0(0.0)$ & .074 \\
\hline Thrombolysis on this admission & $34(0.8)$ & $2(1.6)$ & .28 \\
\hline Smoking history & 2970 (65.9) & 86 (69.9) & .35 \\
\hline Respiratory disease & $647(14.4)$ & $20(16.3)$ & .55 \\
\hline Chronic obstructive pulmonary & $449(10.0)$ & $14(11.4)$ & .60 \\
\hline \multicolumn{4}{|l|}{ Preoperative medications } \\
\hline ACE inhibitor/ARB & $3026(67.2)$ & $85(69.1)$ & .65 \\
\hline Beta-blocker & $3023(67.1)$ & $92(74.8)$ & .072 \\
\hline Calcium channel blocker & $1451(32.2)$ & $32(26.0)$ & .15 \\
\hline Nitrate & $1751(38.9)$ & $47(38.2)$ & .89 \\
\hline Statin & $3952(87.7)$ & 113 (91.9) & .16 \\
\hline Amiodarone & $63(1.4)$ & $3(2.4)$ & .34 \\
\hline Digoxin & $100(2.2)$ & $1(0.8)$ & .29 \\
\hline Diuretic & $1078(23.9)$ & $29(23.6)$ & .93 \\
\hline Other NSAID within $3 \mathrm{~d}$ & $44(1.0)$ & $4(3.3)$ & .014 \\
\hline Clopidogrel within $7 \mathrm{~d}$ & $130(2.9)$ & $1(0.8)$ & .17 \\
\hline Warfarin within $7 \mathrm{~d}$ & $50(1.1)$ & $1(0.8)$ & .76 \\
\hline Heparin in previous $24 \mathrm{~h}$ & $346(7.7)$ & $8(6.5)$ & .63 \\
\hline Randomized to TxA & 2237 (49.6) & $73(59.3)$ & .033 \\
\hline Aspirin exposure & $2965(65.8)$ & $78(63.4)$ & .58 \\
\hline Previous cardiac surgery & $64(1.4)$ & $0(0.0)$ & .18 \\
\hline Combined CABG-valve surgery & $906(20.1)$ & $14(11.4)$ & .017 \\
\hline
\end{tabular}


TABLE E2. Continued

\begin{tabular}{|c|c|c|c|}
\hline Baseline characteristic & Not missing $(n=4507)$ & Missing $(n=123)$ & $P$ value \\
\hline Open chamber surgery & 965 (21.4) & $17(13.8)$ & .042 \\
\hline Isolated CABG & $3448(76.5)$ & $105(85.4)$ & .022 \\
\hline $\begin{array}{l}\text { Type of surgery } \\
\text { On-pump } \\
\text { Off-pump }\end{array}$ & $\begin{array}{c}4336(96.9) \\
137(3.1)\end{array}$ & $\begin{array}{c}117(95.9) \\
5(4.1)\end{array}$ & .51 \\
\hline Most recent platelet count & $233.7(65.2)$ & $261.0(73.6)$ & $<.001$ \\
\hline Most recent APTT & $32.9(13.7)$ & $31.3(11.1)$ & .22 \\
\hline Most recent INR & $1.0(0.1)$ & $1.0(0.1)$ & .28 \\
\hline Most recent serum creatinine & $92.9(37.3)$ & $91.5(28.2)$ & .69 \\
\hline
\end{tabular}

TABLE E3. Risk-adjusted 1-year outcomes according to treatment group, adjusting for variables predicting missingness (from Table E2, those with $P$ value $<.05)$ : age, weight, diabetes status, combined CABG-valve surgery, open chamber surgery, isolated CABG, EuroSCORE, most recent platelet count (other NSAID within 3 days was omitted from regression models due to collinearity)

\begin{tabular}{lcc}
\hline \multicolumn{1}{c}{ Outcome } & RR $(\mathbf{9 5} \% \mathbf{C I}) *$ & Adjusted $\boldsymbol{P}$ value \\
\hline $\begin{array}{l}\text { Primary outcome } \\
\quad \text { Death or disability } \dagger, \ddagger\end{array}$ & $0.83(0.62-1.11)$ & .20 \\
Secondary outcomes at $1 \mathrm{y}$ & & \\
MACE & $0.83(0.72-0.96)$ & .011 \\
Myocardial infarction & $0.85(0.72-1.02)$ & .079 \\
Stroke & $0.67(0.45-0.99)$ & .045 \\
Death & $0.82(0.59-1.13)$ & .23 \\
\hline
\end{tabular}

$R R$, Relative risk; $C I$, confidence interval; $M A C E$, major adverse cardiovascular events, consisting of myocardial infarction, stroke, or death from any cause. *RRs from binary regression models with logarithmic link. †Disability is defined by a Katz activities of daily living score of less than 8 (ie, severe). †Counts of missing outcomes for myocardial infarction and stroke exclude participants who had died. 
TABLE E4. Risk-adjusted RRs of 1-year outcomes for patients randomly assigned to tranexamic acid and according to aspirin exposure, adjusting for variables predicting missingness (from Table E2, those with $\boldsymbol{P}$ value $<.05$ ): age, weight, diabetes status, combined CABG-valve surgery, open chamber surgery, isolated CABG, EuroSCORE, most recent platelet count (other NSAID within 3 days was omitted from regression models due to collinearity)

\begin{tabular}{|c|c|c|c|c|c|}
\hline \multirow[b]{2}{*}{ Outcome } & \multicolumn{2}{|c|}{$\begin{array}{c}\text { Randomized to tranexamic acid and } \\
\text { exposed to aspirin }\end{array}$} & \multicolumn{2}{|c|}{$\begin{array}{c}\text { Randomised to tranexamic acid and } \\
\text { not exposed to aspirin }\end{array}$} & \multirow[b]{2}{*}{ Interaction $P$ value } \\
\hline & $\mathbf{R R}(95 \% \mathbf{C I}) *$ & Adjusted $P$ value & RR $(95 \% \text { CI })^{*}$ & Adjusted $P$ value & \\
\hline \multicolumn{6}{|l|}{ Primary outcome } \\
\hline Death or disability $\dagger$ & $0.70(0.48-1.01)$ & .055 & $1.13(0.70-1.82)$ & .63 & .12 \\
\hline \multicolumn{6}{|l|}{ Secondary outcomes } \\
\hline MACE & $0.79(0.66-0.95)$ & .013 & $0.90(0.71-1.13)$ & .37 & .42 \\
\hline Myocardial infarction & $0.80(0.64-1.00)$ & .051 & $0.96(0.72-1.27)$ & .75 & .33 \\
\hline Stroke & $0.67(0.42-1.08)$ & .10 & $0.66(0.32-1.35)$ & .25 & .96 \\
\hline Death & $0.73(0.49-1.09)$ & .13 & $1.02(0.59-1.78)$ & .93 & .33 \\
\hline
\end{tabular}

$R R$, Relative risk; $C I$, confidence interval; $M A C E$, major adverse cardiovascular events, consisting of myocardial infarction, stroke, or death from any cause. *RRs from binary regression models with logarithmic link. The models include an interaction term between tranexamic acid group and actual aspirin exposure. $\dagger$ Disability is defined by a Katz activities of daily living score of less than 8 (ie, severe).

TABLE E5. Dose effect: comparison of the 2 doses of tranexamic acid used in the trial

\begin{tabular}{|c|c|c|c|c|c|c|c|c|c|}
\hline \multirow[b]{2}{*}{ Outcome } & \multicolumn{4}{|c|}{ Tranexamic acid $1.0 \mathrm{~mL} / \mathrm{kg}$} & \multicolumn{4}{|c|}{ Tranexamic acid $0.5 \mathrm{~mL} / \mathrm{kg}$} & \multirow[b]{2}{*}{$\begin{array}{l}\text { Interaction } \\
P \text { value }\end{array}$} \\
\hline & $\begin{array}{c}\text { Tranexamic } \\
\text { acid } n / N(\%)\end{array}$ & $\begin{array}{l}\text { Placebo } \\
\text { n/N (\%) }\end{array}$ & $\mathbf{R R}(95 \% \mathbf{C I})^{*}$ & $\begin{array}{c}P \\
\text { value }\end{array}$ & $\begin{array}{c}\text { Tranexamic } \\
\text { acid } n / N(\%)\end{array}$ & $\begin{array}{l}\text { Placebo } \\
\text { n/N (\%) }\end{array}$ & $\begin{array}{c}\text { RR } \\
(95 \% \text { CI })^{*}\end{array}$ & $\begin{array}{c}P \\
\text { value }\end{array}$ & \\
\hline \multicolumn{10}{|l|}{ Primary outcome } \\
\hline Death or disability $\dagger$ & $29 / 730$ & $34 / 742(4.58)$ & $0.87(0.53-1.41)$ & .56 & $55 / 1507(3.65)$ & $66 / 1528(4.32)$ & $0.84(0.60-1.20)$ & .35 & .93 \\
\hline \multicolumn{10}{|l|}{ Secondary outcome } \\
\hline MACE & $128 / 739(17.32)$ & $152 / 754$ & $0.86(0.69-1.06)$ & .16 & $197 / 1529(12.88)$ & $224 / 1539(14.55)$ & $0.89(0.74-1.06)$ & .18 & .83 \\
\hline $\begin{array}{l}\text { Myocardial } \\
\text { infarction }\end{array}$ & $103 / 728(14.15)$ & $124 / 742$ & $0.85(0.67-1.08)$ & .17 & $136 / 1495(9.10)$ & $150 / 1510(9.93)$ & $0.92(0.73-1.14)$ & .43 & .64 \\
\hline Stroke & $15 / 724(2.07)$ & $16 / 733(2.18)$ & $0.95(0.47-1.91)$ & .88 & $30 / 1492(2.01)$ & $45 / 1506(2.99)$ & $0.67(0.43-1.06)$ & .089 & .42 \\
\hline Death & $21 / 740(2.84)$ & $28 / 751(3.73)$ & $0.76(0.44-1.33)$ & .34 & $47 / 1527(3.08)$ & $50 / 1538(3.25)$ & $0.95(0.64-1.40)$ & .78 & .53 \\
\hline
\end{tabular}

$R R$, Relative risk; $C I$, confidence interval; $M A C E$, major adverse cardiovascular events, consisting of myocardial infarction, stroke, or death from any cause. * RRs from binary regression models with logarithmic link. The models include an interaction term between tranexamic acid group and actual aspirin exposure. $\nmid$ Disability is defined by a Katz activities of daily living score of less than 8 (ie, severe). 